\title{
CONTROLE SOCIAL E PRODUÇÃo DE POLÍTICAS ATRAVÉS DE CONTRATOS: PARCERIAS PÚBLICO-PRIVADAS DE MINAS GERAIS E SÃO PAULO NO PERÍODO 2005-2015
}

\author{
Marilene de Souza Campos ${ }^{2}$ \\ Lara Luíza Silva ${ }^{3}$ \\ Laís Barbosa Vieira ${ }^{4}$ \\ Sinara Guimarães ${ }^{5}$
}

http://dx.doi.org/10.1590/1413-2311.299.97769

\section{RESUMO}

As Parcerias Público-Privadas (PPPs) surgem como instrumentos da administração pública brasileira, no contexto das políticas de desestatização, iniciadas em 1995 pelo Plano Diretor da Reforma do Estado. Essa reforma e a busca por maior governança se basearam na experiência do New Public Management, trazendo consigo os princípios do gerencialismo e do governo por contratos (GAUDIN, 2007). O objetivo deste trabalho é analisar os instrumentos de participação social presentes na legislação das parcerias público-privadas de São Paulo e Minas Gerais (2005-2015), sob a perspectiva deliberativa da democracia. Através do método da análise bibliográfica e documental, observamos o escopo e a obrigatoriedade da participação social, identificando os instrumentos consulta pública, audiência pública e composição dos conselhos gestores. Concluímos que a consulta pública é o único instrumento de participação

\footnotetext{
${ }^{1}$ Recebido em 20/10/2019, aceito em 14/7/2020.

${ }^{2}$ Universidade Federal de Viçosa. Mestrado Profissional em Administração Pública em Rede Nacional, Rio Parnaíba, MG (Brasil); http://orcid.org/0000-0002-3896-4222; marilenecampos@ufv.br.

${ }^{3}$ Universidade federal de Viçosa, Rio Paranaíba - MG (Brasil); http://orcid.org/0000-0002-1527-5395; lara_luiza_rpa@hotmail.com.

${ }^{4}$ Universidade federal de Viçosa, Rio Paranaíba - MG (Brasil); http://orcid.org/0000-0001-5642-779X; lais.barbosa@ufv.br.

${ }^{5}$ Universidade federal de Viçosa, Rio Paranaíba - MG (Brasil); http://orcid.org/0000-0001-8712-7570; sinara.guimaraes@ufv.br.

(c) (1) (9) REAd | Porto Alegre - Vol. 26 - N. 3 - Setembro / Dezembro 2020 - p. 673-708.
} 
efetivamente obrigatório nas PPPs. Nos conselhos gestores de parcerias, observa-se a participação de representantes do Estado e/ou participantes com perfil técnico, marcada pela ausência de representantes da sociedade civil. Trata-se de uma composição e de uma adoção de instrumentos que enfraquece o caráter deliberativo da democracia. Por fim, levantamos diversos casos de parcerias que apresentam problemas legais, financeiros e contratuais, com intuito de sugerirmos uma agenda de pesquisa.

Palavras-chave: Parcerias Público-Privadas. Participação Social. Conselhos Gestores. Consultas Públicas. Audiências Públicas.

\section{CONTROL SOCIAL Y PRODUCCIÓN DE POLÍTICAS A TRAVÉS DE CONTRATOS: ALIANZAS PÚBLICO-PRIVADAS DE MINAS GERAIS Y SAO PAULO EN EL PERÍODO 2005-2015}

Las asociaciones público-privadas (APP) emergen como instrumentos de la administración pública brasileña, en el contexto de las políticas de privatización, iniciadas en 1995 por el Plan Maestro de Reforma del Estado. Esta reforma y la búsqueda de una mayor gobernanza se basaron en la experiencia de la Nueva Gestión Pública, trayendo consigo los principios de gerencialismo y gobierno por contrato (GAUDIN, 2007). El objetivo de este trabajo es analizar los instrumentos de participación social presentes en la legislación de asociación públicoprivada de São Paulo y Minas Gerais (2005-2015), bajo la perspectiva deliberativa de la democracia. Mediante el método de análisis bibliográfico y documental, observamos el alcance y la obligación de la participación social, identificando los instrumentos de consulta pública, audiencia pública y composición de los consejos de administración. Concluimos que la consulta pública es el único instrumento de participación efectiva en las APP. Los consejos de gestión de asociaciones incluyen la participación de representantes del Estado y / o participantes con un perfil técnico, marcado por la ausencia de representantes de la sociedad civil. Es una composición y adopción de instrumentos que socava el carácter deliberativo de la democracia. Finalmente, planteamos varios casos de asociaciones que presentan problemas legales, financieros y contractuales, para sugerir una agenda de investigación.

Palabras-clave: Asociaciones público-privadas. Participación social Consejos de gestión. Consultas publicas. Audiencias públicas. 


\section{SOCIAL CONTROL AND POLICY PRODUCTION THROUGH CONTRACTS: PUBLIC-PRIVATE PARTNERSHIPS OF MINAS GERAIS AND SAO PAULO IN THE PERIOD 2005-2015}

Public-Private Partnerships (PPPs) emerge as instruments of the Brazilian public administration, in the context of the privatization policies, initiated in 1995 by the State Reform Master Plan. This reform and the pursuit of greater governance were based on the experience of New Public Management, bringing with it the principles of managerialism and contract government (GAUDIN, 2007). The objective of this paper is to analyze the instruments of social participation present in the public-private partnership legislation of São Paulo and Minas Gerais (2005-2015), under the deliberative perspective of democracy. Through the method of bibliographic and documentary analysis, we observed the scope and the obligation of social participation, identifying the instruments public consultation, public hearing and composition of the management councils. We conclude that public consultation is the only instrument of effective participation in PPPs. Partnership management councils include the participation of representatives of the State and / or participants with a technical profile, marked by the absence of representatives of civil society. It is a composition and adoption of instruments that undermines the deliberative character of democracy. Finally, we raise several cases of partnerships that present legal, financial and contractual problems, in order to suggest a research agenda.

Keywords: Public-Private Partnerships. Social Participation. Management Councils. Public consultations. Public hearings.

\section{INTRODUÇÃO}

As Parcerias Público-Privadas (PPPs) surgem como instrumentos da Administração Pública Brasileira, no contexto das políticas de desestatização, iniciadas em 1995, pelo Plano Diretor da Reforma do Estado. Essa Reforma Administrativa e a busca por maior governança, que a caracterizou, se baseou no New Public Management, trazendo consigo os princípios do gerencialismo e do governo por contratos (GAUDIN, 2007). No Brasil, a reforma elevou a noção de eficiência e o gerencialismo ao status de princípio constitucional, a partir da aprovação da Emenda n¹9/1998. A adoção de novas figuras contratuais se deu sob a influência (c) $(1) \Theta$ 
da cultura dos contratos, desenvolvida na Grã-Bretanha dos governos conservadores, que produziram a descentralização dos serviços, segundo o modelo do Enabling State.

Observa-se uma tendência à contratualização das políticas públicas, nas quais tratativas públicas que se cumpriam unilateralmente, baseadas em critérios legais ou técnico-científicos, são remetidas a uma negociação conduzida de forma bi ou plurilateral, envolvendo uma diversidade de atores e assumindo um caráter explícito no que se refere ao interesse público (BOBBIO, 2000). Essa nova forma de governar estabeleceu parcerias com as organizações sociais e com o setor privado atendendo aos anseios de privatização do Estado. Entretanto, as parcerias público-privadas não constituem, segundo Hungaro (2016) a mera aplicação de um mecanismo que produzirá resultados esperados, mas um processo dependente da "legitimação por assimilação democrática" (p. 379).

As parcerias público-privadas no Brasil entram na instrumentação pública a partir da Lei $n^{\circ} 8987 / 1995$ - Lei Geral de Concessões, promulgada um pouco antes do Plano Nacional de Desestatização de Empresas (PNDE) e somente em 2004 surge a Lei 11.079 - Lei das Parcerias Público-Privadas. A Lei 11.079/2004 avança no sentido de caracterizar as parcerias público-privadas diferenciando-as das concessões comuns previstas pela Lei 8987/1995. Portanto não vem a se constituir parceria público-privada a concessão comum de serviços públicos ou de obras públicas de que trata a Lei 8987/1995, “§ $3^{\circ}$ quando não envolver contraprestação pecuniária do parceiro público ao parceiro privado". Assim, a diferença substancial centra-se na remuneração do parceiro privado, sendo que nas concessões comuns previstas pela primeira lei, a remuneração do concessionário seria advinda exclusivamente de tarifas cobradas aos usuários e já nas parcerias público-privadas, conforme legislação de 2004, do pagamento de contraprestação por parte da administração pública, com ou sem cobrança de tarifa dos usuários, a depender da modalidade adotada: administrativa ou patrocinada.

No Brasil, o processo de implementação das PPPs apresenta diferenças para cada Estado, sendo caracterizado em alguns, por uma atitude mais ousada, como é o caso de MG, GO, SP e SC, os quais se anteciparam à União na edição de leis que regulamentavam a instituição das PPPs e vêm se destacando como pioneiros neste tipo de contratação, contando com projetos de PPPs para as áreas de saneamento básico, transporte rodoviário e emissário submarino (PECI; SOBRAL, 2007). As diferenças ocorrem também na adoção de instrumentos de participação social, na maioria dos estados brasileiros somente a consulta pública é obrigatória, enquanto alguns estados adotam também a audiência pública, como discutiremos adiante (MORENO, 2016). No caso de Minas Gerais, as parcerias surgem no contexto da 
reforma administrativa do Governo Aécio Neves (2003-2010), que segundo Peci et al. (2010), foram adotadas em razão da escassez de recursos para a realização de grandes obras e da disponibilidade de capital privado e partilha de riscos que proporcionam. A prefeitura de São Paulo também foi influenciada pela agenda das reformas administrativas dos anos 90 . Nessa mesma esteira, perseguiram-se os aspectos gerenciais que seguem a lógica da eficiência, da agilidade e de melhores resultados (KEINERT, 1993).

O modelo de contratualização das políticas públicas (GAUDIN, 2007) envolve elementos de monitoramento, fiscalização, avaliação e participação que elevam muito o custo das transações, mas asseguram a qualidade democrática dos processos (PECI et al., 2010). Os mecanismos de participação e controle social que vem sendo inseridos na conjuntura brasileira nas últimas décadas por meio do paradigma da gestão pública participativa (orçamento participativo, legislações visando assegurar maior transparência e accountability, como a Lei $n^{0}$ 12.527/2011 de Acesso à Informação) e no caso analisado, os conselhos gestores, audiências e consultas públicas, apresentam-se como um inquestionável produto democrático, por meio dos quais os beneficiários das parcerias tornam-se parte da elaboração dos contratos, gestores e fiscalizadores. Não obstante as diversas vantagens econômicas e políticas, decorrentes da disponibilização de capital dos contratos explícitos e da governança, observamos relatos que surgem na mídia nas fases de implementação das PPPs, de mau funcionamento devido a fraudes, prevaricação, prejuízos, quebras de contrato e outras modalidades de problemas. Instrumentos societários incorporados com o intuito de conferir transparência e fiscalização, parecem não funcionar como medidas de controle por parte da sociedade. Nesse sentido, o propósito do presente trabalho é a realização de considerações teóricas e empíricas e de uma problematização de investigação sobre o aspecto da institucionalidade das concertações no âmbito da contratualização das políticas públicas na modalidade PPP e, desse modo, apresentar uma agenda de pesquisa consistente sobre o tema. O objetivo é analisar os instrumentos de participação social presentes na legislação das parcerias público-privadas de São Paulo e Minas Gerais (2005-2015), sob a perspectiva deliberativa da democracia. A partir dos estudos bibliográficos e documentais, identificamos os instrumentos consulta pública, audiência pública e participação no conselho gestor de parcerias como os mais relevantes ou presentes no texto legislativo.

Foram analisados documentos sobre a incorporação da participação como instrumento de gestão no texto da legislação, dos manuais e dos contratos, tendo em vista o poder deliberativo, fiscalizador e de enforcement da sociedade civil. Em caráter de análises 
complementares, foram selecionadas notícias de jornais, identificando os problemas que surgem na mídia relativos aos contratos das PPPs em Minas e São Paulo. Analisamos os instrumentos jurídicos de participação social previstos na constituição e na legislação, que formatam a modelagem dos contratos e identificamos vulnerabilidades dos instrumentos de participação que poderiam ser modificados e contribuir com os processos de controle social.

A contribuição primária do presente artigo é trazer para o debate sobre as parcerias a temática de participação, à luz de uma teoria que apresenta certo ineditismo no Brasil, ou seja, a abordagem de Gaudin (2007) acerca da administração pública através de contratos, associando-a a teoria da democracia deliberativa de Habermas. Tal associação é sugerida por Bobbio (2000). A abordagem da contratualização da política envolve acordo de concertação sobre uma diversidade de bens e recursos públicos, operando de contratos formalmente e legalmente estabelecidos a contratos informais. Secundariamente, a contribuição é trazer a reflexão de que o controle social das políticas públicas é um potencial de eficiência tão significativo quanto o aspecto técnico, tão valorizado pelas premissas do gerencialismo. Contratos são instrumentos da esfera privada, dos mercados, que passam a integrar sob a forma de concertação a ação pública. Essa modalidade de gestão deveria, em tese, trazer a sociedade civil para a relação contratual. Acreditamos que a ausência da sociedade civil da contratualização não é o único fator a explicar os inúmeros problemas de improbidade, descumprimento dos contratos e outros elementos de fraude e fracasso, mas um fator que poderá contribuir para minimizar o problema. Além disso, observa-se que os trabalhos que se propõem a discutir a temática estão circunscritos ao enfoque gerencial, da racionalidade e eficiência desse tipo de contrato (THAMER; LAZZARINI, 2015, PECI et al., 2012), o que denota uma lacuna teórica a ser discutida do ponto de vista da participação e do controle social sobre esses instrumentos como forma de contribuição para sua efetividade. Relacionar a temática da democracia deliberativa à abordagem das novas figuras contratuais traz uma nova perspectiva para a análise das PPPs, cujo impacto é destacar um espaço de participação pouco ocupado pela sociedade civil.

O artigo está organizado da seguinte forma: após esta Introdução, apresenta-se a contextualização sobre Produção de Políticas através de contratos e a Legislação das Parcerias Público-Privadas em Minas e São Paulo, em seguida a Metodologia utilizada para obtenção e tratamento dos dados, logo após os Resultados e Discussões, expondo as considerações sobre as PPPs e os instrumentos de participação popular à luz dos três instrumentos analisados, bem 
como as Condições de Execução das mesmas segundo os relatos de mídia. Por fim, são expostas as Considerações Finais juntamente à proposta de agenda de pesquisa.

\section{PRODUÇÃo de POLÍTICAS ATRAVÉS de CONTRATO: O REDESENHO dA ADMINISTRAÇÃO PÚBLICA}

Nas últimas décadas, acompanhando uma tendência internacional, observa-se na administração pública brasileira um aumento dos casos em que os entes públicos agem muito mais como parte de um contrato do que como decisores únicos. Decisões unilaterais, de caráter técnico ou legal tendem a ser substituídas por relações contratuais de aspecto regulatório, envolvendo atores diversos, sejam eles públicos, privados ou entidades da sociedade civil que assumem compromissos recíprocos. As práticas de contratualização das políticas crescem na instrumentação dos administradores públicos e se baseiam em novas modalidades de contrato. Segundo Bobbio (2000), os novos contratos assumem um caráter explícito, que é justamente o que diferencia o fenômeno da contratualização daquele da negociação. Para Gaudin (2007), os contratos não ocorrem de forma marginal, oculta ou ilegítima, mas se desenvolvem publicamente e a sociedade é informada do fato que se contrata. Ocorre uma formalização dos acordos e as regras são estabelecidas. A diferença dos tradicionais contratos de direito privado é que, nos novos contratos da administração pública, a relação principal-agente não é bilateral, encontramos diversos tipos de acordo entre partes que se dispõem a cooperar por um objetivo comum.

Políticas públicas são sempre objeto de negociação, uma vez que qualquer decisão pública decorre de longos processos de discussão, contratação e trocas nas comissões parlamentares, dentro e fora dos partidos e internamente às policy communities. Entretanto, esse tipo de negociação ocorre de modo relativamente oculto, em um sentido não regulado das normas jurídicas e às vezes se configuram nas margens da legalidade, nem sempre originando contratos efetivamente assinados pelas partes. Essa forma de organização, onipresente e opaca é destinada a permanecer e enraizar todas as escolhas públicas, grandes ou pequenas, que se realizam nos diversos níveis do governo. A novidade dos contratos que emergem dos processos neoliberais de reforma do Estado é o caráter explícito (BOBBIO, 2000, p. 113). Segundo Gaudin (2007), de forma distinta dos contratos bilaterais da administração pública observa-se 
certo grau de formalização dos acordos, estabelecidos em uma modalidade regulatória pelos envolvidos e honrados em contratos assinados pelas partes.

Bobbio (2000) chama atenção para outro aspecto de inovação na produção das políticas; os novos contratos não se assemelham aos contratos normais de direito privado, suas obrigações são atípicas, sua natureza jurídica é incerta:

Os "contratos públicos", justamente porque regulam questões de interesse geral, podem conter relevantes efeitos externos (positivos ou negativos) para sujeitos que não tomaram parte da estipulação do acordo. Enquanto que os "contratos privados" não podem, por definição, ter alguma eficácia no confronto de terceiros, os "contratos públicos" tendem, com muita probabilidade, a produzir algum tipo de externalidade. Em alguns casos, os efeitos externos são explicitamente previstos pela lei que atribui autoridade ao acordo. Isso significa que os sujeitos potencialmente implicados, são induzidos a exercer algum tipo de pressão para participar da mesa de negociação. Às vezes eles são admitidos, às vezes não (BOBBIO, 2000, p. 115, tradução nossa).

É preciso observar que a contratação de caráter privado também cresceu na administração pública dos países que adotaram as medidas de austeridade e redução do tamanho do Estado, alinhando-se com o New Public Management. A terceirização está redesenhando em profundidade a estrutura da administração pública; através do contrato com empresas privadas ou organismos públicos autônomos. Entretanto, a diferença entre os contratos de direito privado da administração pública e os novos é que eles não se enquadram na relação principal-agente. A administração pública, como principal, assume a posição de contratante de um agente que desenvolverá, por sua própria conta, uma atividade, e terá os objetivos e interesses assegurados por cláusulas contratuais. São os contratos bilaterais principal-agente que serão substituídos por acordos de cooperação entre as partes, nos quais se torna difícil distinguir o principal-agente. $\mathrm{O}$ objeto dos contratos nesse caso passa a ser o consenso ou a concertação em torno de uma linha de intervenção, um projeto e o compromisso recíproco das partes em cooperar (GAUDIN, 2007).

A contratualização das políticas e as negociações, em suas novas modalidades entre parceiros públicos e privados, apresenta-se como inovação que reestrutura em profundidade a Administração Pública contemporânea. A redefinição das políticas públicas no Brasil se manifesta na multiplicação de contratos de parceria, envolvendo vários níveis da Administração Pública. A combinação dos princípios de participação incorporados pela Constituição de 1988, progressivamente implementados, com a introdução das novas figuras contratuais com a Reforma do Estado de 1995, produziu um novo cenário para as políticas de parceria. Essas últimas constituem "formas de ação conjunta entre atores do poder público, agentes econômicos e associativos", o que designa as parcerias público-privadas, objeto deste estudo (GAUDIN, 
2007; PEREIRA, 2005). Tais formatos de cooperação-contratação encontram-se no âmbito das políticas sociais, econômicas ou de desenvolvimento territorial.

O redesenho das políticas públicas do governo por contratos implica, em tese, na adoção de instrumentos de participação e controle social de elevado potencial democrático e deliberativo, através da ampliação da participação democrática. A concepção de controle social é oriunda da sociologia para demonstrar a coerção que estruturas sociais exercem sobre o comportamento de indivíduos, tendo no pensamento de Émile Durkheim sua principal expressão. $\mathrm{Na}$ concepção que adquire na ciência política expressa a ideia de que a sociedade civil exerce um controle sobre o Estado, garantindo a participação, a inclusão e a fiscalização por parte da mesma. A contratualização das políticas públicas se traduz em modalidades de controle social e em instrumentos de democracia participativa.

Teóricos da vertente democrática do participacionismo, Habermas (1995) e Carole Pateman (1992) reescrevem o debate sobre a democracia. Segundo Habermas, a concepção republicana de cidadania enfatiza os direitos à participação e comunicação políticas, ou seja, "autores políticos responsáveis de uma comunidade de pessoas livres e iguais" (HABERMAS, 1995, p.41). Ao analisar a constituição da esfera pública, Habermas a considera um espaço no qual os atores sociais não se movem nem por interesses particularistas nem com o objetivo de dominar outros indivíduos. Na concepção deliberativa de democracia defendida por Habermas, o uso da razão estabelece uma relação entre argumentação pública e participação, apresentado uma dimensão argumentativa no interior na relação Estado/sociedade, que faz com que a opinião dos indivíduos não possa ser reduzida à vontade da maioria (AVRITZER, 2000). Segundo a contribuição de Pateman (1992) a participação é um potencial de intervenção e influência nos processos decisórios fundamentais à democracia. Deliberar, segundo Habermas, implica em processos, nos quais um ou mais agentes avaliam e debatem questões públicas e se fazem implicar, em termos de influência nas decisões (AVRITZER, 2000). Os conselhos gestores, que também estão presentes nas PPPs, encontram-se entre os instrumentos da democracia deliberativa, como espaços significativos para a efetivação de seu potencial de deliberação. Vários fatores contribuem para que os conselhos exerçam sua capacidade deliberativa e democrática, dentre eles, o arcabouço institucional que os formata, estabelece as competências e o engajamento e qualidade da participação dos atores. As PPPs através dos conselhos gestores de parcerias, teoricamente, reivindicam em seus textos legais uma participação democrática e deliberativa, envolvendo também instrumentos como consultas e audiências públicas. As PPPs são instrumentos clássicos de postulação da contratualização das 
políticas públicas, e em tese, envolvem multiplicidade de atores no processo decisório combinados a instrumentos formais de contrato, que não são bilaterais como os da iniciativa privada. Contratualização e participação são duas faces dos processos de gestão das políticas públicas.

O formato deliberativo da democracia, que implica na multiplicidade de atores envolvidos no processo de dialogicidade, é o elemento chave para se pensar as PPPs neste trabalho, deslocando da perspectiva técnica da eficiência para a perspectiva política. A adoção de conselhos gestores de parcerias, a utilização de consultas públicas e audiências públicas não necessariamente gerariam processos deliberativos de qualidade se fossem mais formais que efetivamente inclusivos e participativos.

\subsection{A LEGISLAÇÃO DAS PARCERIAS PÚBLICO-PRIVADAS E OS ESTADOS DE MINAS GERAIS E SÃO PAULO}

Para além das parcerias de caráter social, realizadas a partir de contratos de gestão, observamos as tratativas em torno da implantação de infraestrutura e a prestação de serviços públicos diversos por agentes privados que adquirem destaque a partir da Lei $n^{\circ}$ 8.987/1995 Lei Geral das Concessões - na qual se verifica a possibilidade legal de privatização formal da prestação do serviço, conservando na íntegra a titularidade dos mesmos por parte do ente público. Com a promulgação da Lei nº 11.079/2004 - Lei das Parcerias Público-Privadas, são instituídas as normas gerais para licitação e contratação de PPPs no âmbito da Administração Pública. No texto da Lei $n^{\circ} 11.079 / 2004$, as PPPs são definidas como sendo um contrato de prestação de serviços, onde é vedada a celebração de contratos que tenham por objetivo único o fornecimento de mão-de-obra, equipamentos ou execução de obra pública e estabelece ainda um valor mínimo de contrato de $\mathrm{R} \$ 20$ milhões (art. $2^{\circ}, \S 4^{\circ}, \mathrm{I}$ ) e um prazo mínimo de 05 e máximo de 35 anos para os contratos de parceria, já incluindo eventual prorrogação (art. $\left.5^{\circ}, \mathrm{I}\right)$.

Segundo Peci et al. (2010), as PPPs são incluídas na agenda política brasileira com intuito principal de atrair investimentos para o setor de infraestrutura, contudo, apresentam as vantagens adicionais listadas na literatura acadêmica e publicações de organismos internacionais:

Compartilhamento de risco com o setor privado; redução do prazo para implantação dos empreendimentos; estímulo à introdução de inovações; as modernizações e melhorias por parte do setor privado de forma a criar um melhor value for money; a possibilidade de realização de um número maior de projetos; a liberação de recursos públicos para outros projetos prioritários sem condições de retorno financeiro e sem capacidade de serem realizadas por meio de concessões tradicionais ou PPPs; e a 
garantia da qualidade da operação e da manutenção dos serviços concedidos por longo prazo (PECI et al., 2010, p. 3).

Brito e Silveira (2005) ponderam que os contratos de PPPs têm uma estrutura complexa e envolvem elevados custos de transação, por isso não seriam adequados a projetos e serviços de pequena escala, nos quais um potencial ganho de eficiência não comportaria os custos de transação associados. Para dirimir dúvidas quanto ao regime aplicável às PPPs e diferenciá-las das concessões comuns regidas pela Lei $\mathrm{n}^{\circ}$ 8.987/1995, a legislação das PPPs adota uma estrutura conceitual que define como parceria público-privada o "contrato administrativo de concessão, na modalidade patrocinada ou administrativa", em que: concessão patrocinada é a concessão de serviços ou obras públicas de que trata a Lei $n^{\circ} 8.987 / 1995$ quando envolver, adicionalmente à tarifa cobrada dos usuários, complementação de receita pela autoridade pública em forma de contraprestação pecuniária; a concessão administrativa é o contrato de prestação de serviços no qual a Administração Pública é usuária direta ou indireta, cabendo a ela o pagamento integral ao parceiro privado.

Um ponto também relevante de que trata a Lei das PPPs é a questão da repartição dos riscos entre as partes, inclusive os referentes a caso fortuito, força maior, fato príncipe e álea econômica extraordinária, prevista no inciso $\mathrm{V}$ do artigo $4^{\circ}$ e inciso III do artigo $5^{\circ}$. De acordo com Brito e Silveira (2005) este dispositivo representa uma alteração importante do regime tradicional de repartição de riscos entre a administração e os entes privados, uma vez que nos contratos administrativos em geral, regidos pela Lei 8.666/93, o poder público arca com o ônus integral desses riscos, e, no caso da Lei $\mathrm{n}^{\circ} 8.987 / 95$, os riscos dos contratos são transferidos para o ente privado.

Outro aspecto abordado pela Lei $\mathrm{n}^{\circ}$ 11.079/04 diz respeito à Sociedade de Propósitos Específicos - SPE, prevista no art. $9^{\circ}$, o qual declara que antes da celebração do contrato de PPPs entre o setor Público e o Privado, necessariamente deverá ser celebrada entre ambos uma SPE para implantar e gerir seu objeto. A Lei trata ainda do direito do Parceiro Privado de intervir no controle da sociedade, em caso de descumprimento dos contratos de financiamento ou de diminuição dos níveis de retornos a níveis que comprometam a efetivação das obrigações futuras. No entanto, o dispositivo legal (art. $5^{\circ} \S 2^{\circ}$, I) que prevê a cessão do controle da sociedade, não altera o direito da administração de intervir na concessionária para garantir a segurança e a continuidade da prestação do serviço.

Além da legislação federal, os estados de Minas Gerais e São Paulo também possuem regulamentação específica no que tange às parcerias público-privadas. O Estado de Minas Gerais, antecipando a regulamentação federal, promulgou a Lei Estadual n ${ }^{\circ}$ 14.868/2003 que (c) (1) $(9)$ 
normatiza essas parcerias e estabelece as diretrizes do Programa e do Plano Estadual de PPPs. Este dispositivo legal busca conforme seu art. $1^{0}$ "disciplinar e promover a realização de parcerias público-privadas no âmbito da Administração Pública Estadual”. No âmbito estadual também foi instituída em 2003 a Lei Estadual n 14.869, de 16 de dezembro que criou o Fundo de Parcerias Público-Privadas do Estado de Minas Gerais cujo objetivo principal é dar sustentação financeira ao Programa de Parcerias Público-Privadas, bem como especificar seus recursos e estabelecer a organização de seu grupo coordenador.

As demais legislações estaduais aplicáveis às parcerias público-privadas são a Lei Complementar n 91/2006 (resolve acerca da instituição, gestão e extinção de fundos estaduais), Decreto Estadual n 43.702/03 (que instala o Conselho Gestor de PPPs - CGP, determina a sua composição e demais providências) e o Decreto Estadual no 44.565, de 03 de julho de 2007 (que institui o Procedimento de Manifestação de Interesse).

No estado de São Paulo o Programa de Parcerias Público-Privadas foi criado por meio da Lei Estadual 11.688/2004, cujo objetivo é de acordo com o art. 1': "destinado a fomentar, coordenar, regular e fiscalizar a atividade de agentes do setor privado que, na condição de colaboradores, atuem na implementação das políticas públicas voltadas ao desenvolvimento do Estado e ao bem-estar coletivo". Também se aplicam a esse tipo de parceria os Decretos Estaduais: $\mathrm{n}^{\circ}$ 40.000, de 16 de março de 1995, e 41.150, de 13 de setembro de 1996, que tratam das concessões comuns de serviços públicos; o $n^{\circ}$ 48.867, de 10 de agosto de 2004, que regulamenta e institui o programa das PPPs; e o n 61.371 , de 21 de julho de 2015, que institui o procedimento alusivo à apresentação, à análise e ao aproveitamento de estudos, encaminhados pela iniciativa privada ou por órgão ou entidade da Administração Pública Estadual.

Neste contexto, é importante ainda diferenciar as PPPs das privatizações. Para Silva (2007), no primeiro caso, a Administração Pública contrata a iniciativa privada para melhorar serviços que serão prestados ao público ou a si própria, e, nas privatizações, que normalmente ocorrem no curto prazo, o objetivo é de aumentar a arrecadação. Além disso, o conceito de privatização aplica-se à mercantilização ou venda do patrimônio público, através da transferência de ativos, ficando a concessão como instrumento legal para ceder à prestação dos serviços de titularidade pública, regulados pelo Poder Público, remunerados por tarifa, por prazo determinado, a uma sociedade de direito. Desta forma PPPs não são o mesmo que privatização, pois não implicam em alienação definitiva do controle de empresas públicas ou sociedades de economia mista para a iniciativa privada. Ao contrário, acredita-se que com o 
passar dos anos a Administração Pública terá robustecido sua capacidade de prestação de serviços públicos, e não terá seu patrimônio dissipado.

Conforme previsto no art. $4^{\circ}$, inciso IV da Lei $\mathrm{n}^{\circ}$ 11.079/04 uma das diretrizes para a contratação da parceria público-privada é a "responsabilidade fiscal na celebração e execução das parcerias". Assim sendo é necessário um despertar para os riscos que as contratações de longo prazo podem revelar para Administração Pública. O compromisso financeiro assumido pela administração, na forma de contraprestação, deve ser ancorado pelos orçamentos posteriores aos da aquisição da despesa. Diante disso, a Lei das PPPs, em seu artigo 10, evidencia que a contratação seja precedida de licitação na modalidade concorrência, resguardada por estudos técnicos que atendam aos parâmetros de metas fiscais previstos pela Lei de Responsabilidade Fiscal, e condicionando seus efeitos financeiros nos períodos seguintes a compensação do aumento permanente da receita ou redução permanente da despesa. Além disso, os critérios na escolha de projetos devem obedecer a um programa de investimento para conferir o melhor uso dos recursos públicos na execução da provisão de serviços públicos e que desta forma é importante considerar na contratação de PPPs: a demanda social, as opções de contratação e a estimativa do montante mínimo de recursos públicos capazes de oportunizar o projeto. Assim, depreende-se do disposto no Art. $5^{\circ}, \S 2^{\circ}$, Inciso III, da Lei ${ }^{\circ} 11.079 / 04$, que as obrigações constituídas pelos financiadores do projeto junto aos fundos e empresas estatais garantidores das parcerias, poderão ser repassadas ao governo como resgate de operações. Neste caso, é possível dizer que os riscos não são efetivamente compartilhados, ficando sob responsabilidade do Estado os riscos do crédito (LIMA et al., 2005).

\section{METODOLOGIA}

O presente artigo desenvolve uma abordagem teórico-empírica, analisando o fator participação social no arcabouço institucional da regulamentação das parcerias públicoprivadas. Enfatizamos a prescrição de formação dos conselhos, a adoção de audiências e consultas públicas como instrumentos de participação. Trata-se de uma pesquisa descritiva com aportes explicativos, que busca descrever as características do objeto de estudo e identificar fatores que contribuem para a ocorrência de fenômenos, sendo operacionalizada por meio de um estudo de caso nos estados de São Paulo e Minas Gerais (LAKATOS; MARCONI, 1992, GIL, 2008).

Para isso realizou-se uma pesquisa documental analisando a legislação no Manual de Parcerias do Estado de São Paulo e o Manual de Operações do Programa Estadual de Parcerias 
Público-privadas de Minas Gerais. Foram analisadas as Leis Federais $n^{\circ}$ 8.987/1995; $n^{\circ}$ 9.637/1998; $\mathrm{n}^{\circ} 9.790 / 1999, \mathrm{n}^{\circ} 11.079 / 2004 ; \mathrm{n}^{\circ}$ 13.019/2014. Foram também examinadas as Leis Estaduais de São Paulo: no 7.835/1992; no 9.361/1996; Lei Complementar $n^{\circ}$ 846/1998; 11.598/2003; 11.688/2004. Em Minas Gerais foram estudadas: Lei Complementar nº 91/2006; Lei Estadual $n^{\circ} 14.869 / 2003$ e 18.038/2009, Decreto Estadual $n^{\circ} 43.702 / 2003$ e Decreto Estadual $n^{\circ} 44.565 / 2007$.

Ademais, foram coletados dados primários (sem tratamento), nos meios oficiais dos órgãos públicos dos dois estados acerca dos contratos firmados entre o período de 2005 a 2015 em ambos estados. Em Minas Gerais os dados estavam disponíveis em um site específico para as parcerias público-privadas e os dados relacionados às parcerias de São Paulo estavam disponíveis para consulta no site da Secretaria de Governo do Estado.

Posteriormente, para análise complementar, foi realizada pesquisa bibliográfica na base de dados do Google Notícias, com objetivo de localizar reportagens que fizessem menção ou abordassem os contratos de parcerias analisados. As palavras-chave utilizadas foram os nomes dos contratos pesquisados, considerando as notícias publicadas no período de 2011 a 2018 e selecionando aquelas que atendiam ao propósito deste estudo. Os textos foram organizados por contrato e por estado, e em seguida, foi realizada a leitura completa e o recorte de trechos considerados importantes para descrever ou explicar os intervenientes presentes nos processos de contratação, implementação e fiscalização dos mesmos nos dois estados. O objetivo foi levantar dados sobre a situação dos contratos, descrever as principais problemáticas encontradas e analisá-las do ponto de vista da vulnerabilidade / força dos instrumentos de participação, fiscalização e enforcement conforme propõe o artigo.

\section{DISCUSSÃO DOS DADOS}

\subsection{AS PPPs E OS INSTRUMENTOS DE PARTICIPAÇÃO POPULAR}

Na Constituição Federal de 1988, o direito de participação, embora não esteja devidamente regulamentado, se faz presente no artigo 37, parágrafo $3^{\circ}$. O artigo contempla a participação dos usuários na formatação do modo como a política será concebida, implantada e explorada, concebendo que a participação não seja meramente reativa, mas proativa (MORENO, 2016). O reconhecimento do direito à participação aparece na Lei 11.079/2004 e também aparecia no Decreto 8.243/2014 (que previa sobre a Política Nacional de Participação 
Social - PNPS e o Sistema Nacional de Participação Social - SNPS) e que foi recentemente revogado pelo Decreto $n^{\circ}$ 9.759/2019. Essa prerrogativa possibilita aos implicados direta ou indiretamente como usuários de uma utilidade pública de tomar parte na deliberação, execução e controle das ações administrativas. No presente trabalho, dedicamos atenção a três instrumentos de participação e controle social e analisamos sua compreensão na legislação das PPPs, como indicadores do potencial de democracia participativa assegurado por ela.

Entre os instrumentos de participação popular e de controle social destacamos, a partir de pesquisa prévia da menção documental, as consultas públicas, as audiências públicas e a participação social em conselhos gestores de parcerias. De todos os instrumentos previstos legalmente na constituição das PPPs, a consulta pública é o único de realização obrigatória e refere-se exclusivamente às minutas do edital e do contrato, como previsto no artigo 1 , inciso VI da Lei 11.079/2004. Ao adotar a consulta pública como procedimento específico para as PPPs, o artigo 39 da Lei 8.666/1993 a concebe como instrumento com função equivalente às audiências públicas. Contudo, do ponto de vista da qualidade da participação, os instrumentos audiência e consulta pública cumprem funções diferentes e atingem públicos diversos. A audiência reúne em debate dinâmico a sociedade civil, as autoridades e os empresários, que no intervalo de algumas horas debatem assuntos diversos, que podem ser incluídos na agenda pelos participantes. A consulta se caracteriza por contribuições encaminhadas por escrito ao longo de um período determinado. Dessa forma, tanto a dinâmica da deliberação pública, quanto a definição de objetivos, diversidade e ampliação do público participante se tornam prejudicados, uma vez que a audiência tem o potencial de ampliar a participação daqueles que possam ter sua esfera de direitos afetada pelas PPPs (MORENO, 2016). Isto posto, tendo o escopo distinto e atingindo a públicos diversos, a realização das consultas deveriam ser complementares às audiências na formalização das parcerias, bem como a diversidade na composição do Comitê Gestor das Parcerias, que deveria incluir ativamente a participação da sociedade civil, representando os implicados, já que este último atua em todas as fases das parcerias, fiscalizando os procedimentos de formalização, implementação e execução. A consulta pública tem sido o instrumento participativo de maior relevância na elaboração dos contratos de PPP, pois é o único cuja aplicação é legalmente obrigatória, sendo as audiências e a composição popular dos conselhos facultativa.

Cabe observar que a Lei do Processo Administrativo autoriza a realização de audiências públicas "sempre que houver situação relevante" e de consultas públicas "sempre que houver assunto de interesse geral”. Segundo Moreno (2016, p.144) “parece-nos razoável presumir que 
onde houver assunto de interesse geral haverá questão relevante", o que permite afirmar nos termos jurídicos que os mecanismos de audiência e consulta são complementares. As legislações estadual e municipal acerca das PPPs, em sua grande maioria, silenciam-se em relação à obrigatoriedade de realização prévia das audiências públicas antes dos editais, com exceção dos estados de Alagoas, Rio Grande do Sul, Sergipe, Distrito Federal e o município de São Paulo (MORENO, 2016). Nos demais, a audiência pública passa a ser uma liberalidade do gestor.

A Constituição de 1988 também trouxe em seu escopo a proliferação dos conselhos gestores, cujo propósito era aprofundar o aporte democrático da gestão pública e tornar mais eficientes as políticas públicas por meio do controle social. Os conselhos se estruturam como colegiados, dos quais fazem parte representantes governamentais e da sociedade civil, designados democraticamente. A realização do potencial democrático dos conselhos, no caso dos acordos que envolvem a contratualização das políticas públicas, dependerá de regulação concertada caso a caso, como também ocorre com relação às regras dos contratos e de enforcement. Nesse aspecto reside significativa vulnerabilidade na construção dos contratos e na fiscalização da execução das PPPs, ou seja, uma incorporação frágil da participação popular. Em Minas e São Paulo, os contratos excluem atores e instrumentos importantes de participação popular. Casos diversos acontecem no sul do país, que apresenta uma cultura de participação inclusiva que deu origem ao Orçamento Participativo como inovação institucional. A cidade de Novo Hamburgo incorporou nos instrumentos de gestão o controle social, através da modificação da composição do conselho gestor de parcerias. Por meio de um projeto de lei, o executivo municipal alterou a composições do Conselho Gestor do Programa de Parcerias Público Privadas, passando o mesmo a ter 17 integrantes, sendo 9 dos quais membros da sociedade civil. O conselho é composto pelo Chefe de Gabinete; os secretários de Desenvolvimento Econômico, Desenvolvimento Social, Desenvolvimento Urbano e Segurança, três membros de livre escolha do prefeito e nove representantes da sociedade civil, pertencentes paritariamente à Associação Comercial, Industrial e de Serviços de Novo Hamburgo, Campo Bom e Estância Velha (ACI), Sindicato do Comércio Varejista de Novo Hamburgo e da Câmara de Dirigentes Lojistas. O critério da paridade prevalece para assegurar a representação (CÂMARA MUNICIPAL DE NOVO HAMBURGO, 2019).

De acordo com as informações disponibilizadas no site das PPPs de Minas Gerais (2019), o Conselho Gestor de Parcerias Público-Privadas (CGP), é vinculado à Governadoria do Estado e presidido pelo Secretário de Estado de Planejamento e Gestão. Sua composição 
inclui, como membros efetivos, o Advogado Geral do Estado e os Secretários de Estado de Desenvolvimento Econômico, de Fazenda, de Transporte e Obras Públicas, de Desenvolvimento Regional e Política Urbana, de Meio Ambiente e Desenvolvimento Sustentável, e, como membro eventual, o titular da Secretaria diretamente relacionada com o serviço ou a atividade objeto do contrato de parceria público-privada. Com essa constituição não se tem a observância de critérios democráticos de participação e inviabiliza-se essa modalidade de controle social, pois as decisões e ações fiscalizadoras cabem quase exclusivamente ao Estado e os recursos de transparência e accountability. É da competência do Conselho elaborar o Plano Estadual de Parcerias Público-Privadas e aprovar editais, contratos de PPP, seus aditamentos e prorrogações. Ademais, deve realizar, permanentemente, a avaliação geral do Plano Estadual de Parcerias Público-Privadas e apreciar os projetos encaminhados por órgãos ou entidades da Administração Estadual interessados em celebrar parcerias.

No caso de São Paulo, de acordo com o Manual de Parcerias do Estado (2016), o Conselho Gestor das Parcerias Público-Privadas (CGPPP), vinculado ao Gabinete do Governador, é o órgão superior de decisão do Programa Estadual de PPP, sendo composto por até oito membros, sendo o Presidente e o Vice-Presidente indicados pelo Governador. A composição se dá da seguinte forma: Presidente, Secretaria Executiva, Secretário Chefe da Casa Civil, Secretário de Planejamento e Gestão, Secretário da Fazenda, Secretário de Desenvolvimento Econômico, Ciência, Tecnologia e Inovação, Procurador Geral do Estado e até três membros de livre escolha do governador. Ressalta-se que as decisões do CGPPP são tomadas pelo voto da maioria, tendo o Presidente direito ao voto de qualidade. Além dos conselheiros, podem ainda participar das reuniões os titulares de Órgãos Setoriais que tiverem interesse direto em determinado projeto, assim como representantes da CPP (Companhia Paulista de Parcerias) e da UPPP (Unidade de Parcerias Público-Privadas), vinculada à Secretaria de Governo e demais convidados pelo Presidente do CGPPP. Compete ao Conselho Gestor, de modo semelhante a Minas Gerais, definir as prioridades do Programa Estadual de PPP e supervisionar a execução de suas atividades, podendo, inclusive, requisitar servidores da Administração Estadual para esta atuação. Desse modo, qualquer matéria de interesse do Programa estadual de PPP deve ser deliberada pelo CGPPP.

No que diz respeito à composição dos Conselhos Gestores, nota-se que a participação da sociedade civil ou de membros que a represente de forma direta, praticamente inexiste, apresentando uma fragilidade do ponto de vista dos aspectos democráticos e de inclusão de 
interesses diversos. Observa-se a preponderância de uma abordagem técnico-gerencial, que subordina a perspectiva democrática. O gerencialismo associou-se em suas origens britânicas a padrões regulatórios que acompanharam a redução do tamanho do Estado e incorporaram instrumentos de controle social (PAES DE PAULA, 2016). Em relação à realização das consultas, conforme exposto anteriormente, embora haja previsão para a realização das mesmas em ambos os Estados, sua contribuição é limitada do ponto de vista da construção coletiva e da qualidade da participação, haja vista estar circunscrita apenas a contribuições encaminhadas por escrito, não havendo espaço para debates e discussões anteriores que poderiam culminar em redesenho ou alteração de projetos ou mesmo das deliberações que afetam a sociedade civil, parte também interessada e atingida pelos processos.

No caso de Minas Gerais, o Manual faz menção às audiências apenas afirmando que é um meio de comunicação entre os agentes, incluindo-as juntamente às sessões públicas de caráter informativo, não mencionando de sua obrigatoriedade ou ocorrência. Desta forma, observa-se que os mecanismos de participação e controle social, a igualdade de oportunidades e mesmo o tratamento isonômico carecem de maior atenção por parte da própria legislação e ao que tudo indica, também de maior efetividade, uma vez que conforme será exposto adiante, a ocorrência de problemas como fraudes, corrupção, não cumprimento de prazos e prejuízos de diversas naturezas têm sido recorrentes nos contratos de PPPs dos Estados analisados, o que poderia ser resguardado ou mesmo amenizado nas fases de concertação e contratualização desses arranjos, uma vez que a elaboração criteriosa dos contratos é um fator-chave para o êxito das parcerias (PÉRICO; REBELATTO, 2005).

\subsection{A MÍDIA E AS CONDIÇÕES DE EXECUÇÃO DAS PPPs EM MINAS GERAIS E SÃO PAULO}

Em perspectiva complementar, procedemos os levantamentos das características das parcerias dos dois estados brasileiros, Minas Gerais e São Paulo, no período de 2005 a 2015, de acordo com as informações disponíveis para consulta em meios oficiais online acerca dos contratos de parcerias público-privadas já em andamento. Esse levantamento foi fundamental para a conclusão de que os instrumentos contratuais estão falhando em sua modelagem, fiscalização e sanção, elementos que poderiam contar com o suporte de um controle social fortalecido. Assim foram observadas as peculiaridades das parcerias de cada estado no que diz respeito à data de assinatura do contrato, valor de investimento, área, localização das obras e tipo de contrato. 
As análises permitem inferir que os dois estados iniciaram seus investimentos em PPPs na mesma época, sendo que o primeiro contrato de parceria estabelecido foi por MG, assinado em 2007, e em 2006 por SP. A Lei Federal de PPPs foi publicada em um cenário onde os recursos públicos para investimentos em infraestrutura eram limitados. Em relação à fiscalização, os dois estados possuem um conselho gestor responsável por aprovar, fiscalizar e acompanhar os projetos. Dentro do período estabelecido para análise identificou-se um total de 21 (vinte e um) contratos de PPPs, sendo 11 (onze) deles assinados no estado de São Paulo e 10 (dez) no estado de Minas Gerais. Além das leis que determinam aspectos das parcerias público privadas, cada estado tem um manual de padronização das regras de parceria, onde definem sobre a execução dos estudos, modelagem, licitação, gestão do contrato, fiscalização, e demais informações necessárias aos investidores e a equipe técnica. Inúmeros gestores públicos, executivos e consultores com experiência se dedicam aos modelos de PPP, e mesmo assim podem ocorrer falhas em diversos contratos dessa natureza, conforme veremos a seguir. No que se refere à data, em sua maioria foram firmados no estado de São Paulo entre 2013 e 2014, na gestão do governador Geraldo Alckmin, e no estado de Minas Gerais grande parte dos contratos foram assinados em 2014, na gestão do governador Antônio Anastasia. Ambos os governadores pertenciam ao partido PSDB e são pioneiros no assunto de parceria público privadas, já que os próprios aprovaram a Lei Estadual de PPPs do seu estado e atuaram apoiando a implementação das parcerias.

São Paulo apresentou maior número de contratos de parceria firmados assim como um investimento financeiro mais elevado, em torno de 63,8 bilhões, enquanto que em Minas Gerais foram investidos em torno de 10 bilhões. Em Minas o programa de Resíduos Sólidos Urbanos (para operação de aterro sanitário e tratamento dos resíduos sólidos provenientes da limpeza urbana), uma parceria assinada no ano de 2014, com valor de $\mathrm{R} \$ 2.441 .177 .411 .49$, na área de saneamento e modalidade administrativa, foi o que apresentou maior aplicação de capital, 2,4 bilhões que representam $24 \%$ dos investimentos do estado. Este foi um contrato, em que de acordo com a reportagem do Jornal O TEMPO (2018), houve incidência de fraude e corrupção por meio do direcionamento de licitação, conforme se observa:

O governador de Minas, Fernando Pimentel (PT), e o secretário de Estado de Transportes e Obras Públicas, Murilo Valadares, foram condenados pela Justiça por direcionar a licitação do serviço de aterro sanitário de Belo Horizonte, quando atuavam na prefeitura da capital. [...] Também foram condenados o então presidente da Comissão de Licitação da Secretaria de Políticas Urbanas, Gustavo Alexandre Magalhães, e a empresa que teria sido beneficiada pelo direcionamento, a Vital Engenharia Ambiental (O TEMPO, 2018, grifo nosso). 
De forma semelhante, o projeto de Reforma do Complexo do Mineirão, assinado no ano de 2010, com o valor de $\mathrm{R} \$ 677.353 .021,85$, na área do esporte e modalidade administrativa, também foi alvo deste tipo de problemática, envolvendo improbidades como fraudes em balanços oficiais da empresa concessionária, corrupção e lavagem de dinheiro, conforme demonstram os trechos das reportagens a seguir:

\footnotetext{
Entre outras manobras, a concessionária (formada pelas empresas Construcap, Egesa e Hap Engenharia) teria fraudado números de seus balanços oficiais, como lucro líquido resultante da exploração do estádio e receitas obtidas com a venda de ingressos (SEGALLA, 2016, grifo nosso).
}

A pedido do Ministério Público (MP), a Justiça determinou a quebra do sigilo bancário da Minas Arena, concessionária que administra o Mineirão, com o objetivo de verificar se as informações da Parceria Público-Privada (PPP) estão sendo encaminhadas corretamente para o Estado. A solicitação é referente ao período de janeiro de 2012 a dezembro de 2016 e foi acatada pela juíza Patrícia Santos Firmo em março deste ano (NOGUEIRA, 2017).

O empresário Joesley Batista afirmou à Lava Jato que pagou 30 milhões de reais em propina ao governador mineiro por meio da compra de $3 \%$ das ações do Mineirão, em 2014. A transferência do valor para o suposto caixa 2 da campanha de Pimentel teria sido intermediada pela HAP Engenharia, uma das empresas do consórcio Minas Arena (PIRES, 2018, grifo nosso).

As análises no estado de São Paulo demonstram que a área que recebeu maior investimento financeiro foi a de transporte, com os contratos de concessão patrocinada de prestação dos serviços públicos de transporte de passageiros, recebendo um investimento de 23,1 bilhões, $37 \%$ do total das obras estaduais. Condutas semelhantes acerca de fraude, corrupção, lavagem de dinheiro e improbidades nas licitações, foram identificadas, na parceria Linha 8 - Diamante (para manutenção e modernização de material rodante, aquisição de 36 novos trens), assinada no ano de 2010, com o valor de $\mathrm{R} \$ 1.802 .440 .214,02$, na área de transporte e modalidade administrativa:

A Justiça de São Paulo aceitou a denúncia contra sete executivos acusados de cartel e fraude à licitação de 2009 [...] em São Paulo, para a criação de uma Parceria Público Privada (PPP) no setor metro ferroviário [...] houve crime financeiro e crime contra a administração pública, pois executivos da Alstom, CAF, Bombardier, Siemens, MGE, Mitsui e Tejofran teriam discutido estratégias para dividir o certame e até fazer parcerias [...] a denúncia aponta que a CAF já sabia que as outras empresas não iriam apresentar proposta para a licitação, o que configurou uma "competição sem competidores"[...] e ofereceu o preço que bem entendeu seguramente muito acima daquele que resultaria de ambiente competitivo, já que não encontraria qualquer resistência (COUTINHO, 2016, grifo nosso).

[...] O cartel era um jogo de cartas marcadas. As empresas não só superfaturavam em até $30 \%$ o preço das obras e dos trens, como combinavam qual delas faria a proposta vencedora de determinada licitação. Pelo acordo, quem vencia a licitação subcontratava as perdedoras. Para o esquema funcionar, as empresas pagavam propina a servidores públicos (G1, 2016, grifo nosso). 
A parceria da Linha 6 - Laranja (para implantação e operação de 15,3 km da linha Brasilândia-São Joaquim, 15 estações e 23 trens) em São Paulo, assinada no ano de 2013, com o valor de $\mathrm{R} \$ 23.138 .729 .185,58$, na área de transporte e modalidade patrocinada, também foi alvo de problemas dessa natureza. De acordo com as reportagens, ocorreram repasses ilícitos de valores pertencentes à obra para o pagamento de propina por alterações encomendadas no edital e financiamento de campanhas eleitorais, incorrendo em prejuízos e atrasos nas obras.

\begin{abstract}
Repasses ilícitos teriam sido feitos de abril a outubro de 2014 a Marcos Monteiro, segundo delação. Valores saíam dos custos das obras da Linha 6 - Laranja do Metrô [...] As obras da Linha, que ligaria o Centro à Zona Norte de São Paulo, estão paradas desde o final de 2016. De acordo com Rodrigues, Brasil teria cobrado o pagamento adiantado de propina por ter feito alterações no edital para a construção da linha 6 do metrô. $O$ valor cobrado, segundo o delator, era equivalente a $0,01 \%$ do valor total de $\mathrm{R} \$ 8$ bilhões do contrato das obras (G1b, 2017, grifo nosso).

Operação Lava-Jato trava obras de mobilidade urbana em todo o país. Linha 6Laranja do Metrô de SP é caso emblemático. As obras da Linha 6-Laranja (Brasilândia - São Joaquim), que envolvem R \$ 9,9 bilhões de investimentos, estão paradas desde o ano passado. As empreiteiras que compõem o consórcio construtor estão envolvidas na Operação Lava Jato - Odebrecht, Queiroz Galvão e UTC. Sem conseguir fechar o financiamento com o BNDES para continuar a construção, as obras foram paralisadas. [...] Detalhe: a obra estava com apenas $15 \%$ do projeto executado (PELEGI, 2017, grifo nosso).
\end{abstract}

Em 2017, executivos da Odebrecht disseram em delação premiada que as obras da Linha 6 - Laranja serviram para abastecer o esquema de propina da construtora, para influenciar políticos e financiar o caixa dois de campanhas eleitorais (REIS, 2018, grifo nosso).

Outro impasse encontrado na análise documental enfrentado por esse tipo de arranjo foi o descumprimento de contrato. A parceria da Rodovia MG 050 (para reforma e operação da rodovia MG 050 entre Juatuba e divisa MG - SP da rodovia BR 262) de Minas Gerais, assinada em 2007, com o valor estimado de $\mathrm{R} \$ 2.196 .017 .610,00$, na área de transporte e modalidade patrocinada, incidiu neste tipo de entrave, como demonstram os relatos das reportagens abaixo:

[...] responsável por obras na rodovia é multada em $\mathrm{R} \$ 20$ milhões pelo Estado por descumprimento do contrato [...] já foram abertos 54 procedimentos administrativos para apurar irregularidades na execução do contrato, resultado da primeira parceria público-privada (PPP) do governo mineiro para estradas. Além dessas multas, a concessionária é alvo também de um outro processo[...] para avaliar o não cumprimento dos parâmetros de qualidade previstos no contrato (MELLO, 2015, grifo nosso).

Do total de obras previstas em contrato, apenas $58,1 \%$ foram concluídos e $9,5 \%$ estão em andamento. Outros 8,4\% foram suspensos e $24 \%$ sequer começaram [...] fontes da Setop afirmam que os termos da PPP possibilitam diferentes interpretações jurídicas e dão brechas para os descumprimentos (FREITAS, MELLO, 2016, grifo nosso). 
Infraestrutura da MG-050 é um dos entraves para os negócios em Divinópolis [...] a concessionária descumpriu várias etapas do cronograma e ainda descumpre outras (LELLES, 2018, grifo nosso).

[...] a falta de infraestrutura é apontada pela Associação Comercial de Divinópolis (Acid) como um empecilho para os investidores da região [...] está parada há 11 anos [...] Até o momento, sete termos foram adicionados ao contrato e algumas mudanças que deveriam ser concluídas em 2020 não começaram (MGTV, 2018, grifo nosso).

É possível notar que para além do atraso das obras, irregularidades na execução e ausência de qualidade, chama-se a atenção para a fragilidade dos contratos, uma vez que como apontam Freitas e Mello (2016), estes possibilitam interpretações diversas e abrem margem para descumprimentos dessa natureza.

De forma similar, em São Paulo a parceria da Linha 4 - Amarela (para construção e operação da linha Luz-Vila Sônia com 12,8km, 6 estações e 29 trens), assinada no ano de 2006, com o valor de $\mathrm{R} \$ 790.000 .000,00$, na área de transporte e modalidade patrocinada, foi alvo de descumprimento de contrato e atrasos nas obras:

O governo paulista e a concessionária Via Quatro, responsável pela operação da Linha 4-Amarela do Metrô, estão em meio a uma disputa milionária referente a atrasos na entrega das obras - iniciadas há mais de 12 anos e que até hoje entregaram apenas 6 das 11 estações previstas (IORY, 2016, grifo nosso).

MP investiga suspeita de fraude na construção da Linha 4-Amarela do Metrô de SP. Denúncia anônima aponta desvios de $\mathbf{R} \mathbf{\$} \mathbf{4 7 , 8}$ milhões. Além de fraude licitatória e peculato, funcionários do Metrô e do consórcio são investigados também por corrupção ativa e passiva, falsidade ideológica, falsidade documental, apropriação indébita previdenciária, organização criminosa e lavagem de dinheiro (STOCHERO, 2017, grifo nosso).

Como quatro das 11 estações da linha ainda não foram inauguradas, e as que já estão em operação sofreram atrasos, a Via Quatro cobra uma dívida de 500 milhões de reais do Governo estadual. [...] Além da abertura de uma cratera na estação Pinheiros, em 2007, que matou sete pessoas e atrasou as obras, em 2015 o Governo rompeu o contrato com o consórcio responsável pelo término das obras, alegando que ele havia descumprido termos do que fora acordado. Os trabalhos foram retomados em julho passado, depois de um novo edital. Na melhor das hipóteses, estarão prontos até 2018 , com ao menos oito anos de atraso. O rompimento do contrato é alvo de investigação do Ministério Público, que aponta pagamentos feitos ao consórcio responsável pelas obras em períodos nos quais ela esteve completamente paralisada [...] Em São Paulo, o arranjo que possibilitou as PPPs passa muito mais por questões contratuais do que por um pensamento que englobasse desenvolvimento urbano (OLIVEIRA, 2017, grifo nosso).

A construtora Camargo Corrêa fechou um acordo de leniência com o Conselho Administrativo de Defesa Econômica (Cade) e o Ministério Público Federal de São Paulo (MPF-SP) para relatar caso de suposto cartel em licitações de transporte público - em especial metrô e monotrilho [...] entre elas, seis obras teriam sido atingidas no período de 1998 a 2005: [...] Linha 4 - Amarela do metrô de São Paulo [...] (VEJA, 2017, grifo nosso). 
Anunciada em 1995, a Linha 4-Amarela só teve suas obras iniciadas em 2004. A parceria público-privada foi assinada em 2007. Em 2015, apesar do recebimento de dois aditivos, que totalizaram 40 milhões de reais, o consórcio Isolux-CorsánCorviam, da Espanha, foi descredenciado pelo governo do estado e deixou pela metade quatro estações. Com idas e vindas, acréscimos e desapropriações, a conta da Amarela chegou a 6,5 bilhões de reais (QUINTELLA, 2018, grifo nosso).

SP inaugura estação da linha Amarela com quatro anos de atraso. [...] O estirão para inaugurar várias estações em um curto espaço de tempo não é coincidência. 2018 é ano eleitoral [...] A última estação da linha 4-amarela a ser inaugurada, também não por coincidência, foi a Fradique Coutinho, em 2014, ano em que o governador concorreu à reeleição. As estações Paulista e Faria Lima, as primeiras, foram entregues no também ano eleitoral de 2010. Entre 2017 e meados de 2018, devem ser inauguradas 19 estações de transporte público na capital paulistana. A inauguração de obras faz parte da estratégia [...] para fortalecer o nome no ano eleitoral (EXAME HOJE, 2018, grifo nosso).

As reportagens demonstram que além das quebras contratuais e atrasos, houve ainda investigação para apurar suspeita de fraude licitatória, corrupção, prejuízos financeiros, formação de cartel e utilização deste tipo de contrato para promoção pessoal e eleitoral, já que as inaugurações ocorriam justamente em anos eleitorais, confirmando a tendência dos governos por contrato, conforme exposto por Campos (2009) e Gaudin (2007).

A parceria paulista da Linha 18 - Bronze (para construção e operação do monotrilho na linha Tamanduateí-Djalma Dutra com 15,7 km, 12 estações e 26 trens), assinada no ano de 2014, com o valor de $\mathrm{R} \$ 13.186 .610 .736,27$, na área de transporte e modalidade patrocinada necessitou de diversas prorrogações contratuais, como evidenciam os trechos abaixo:

O Governo de São Paulo prorrogou pela quarta vez o contrato com o Consórcio Vem $\mathrm{ABC}$ para construção da Linha 18-Bronze (Tamanduateí-Djalma Dutra). A obra ainda não saiu do papel [...] Não há previsão de entrega da linha visto que não há prazo para início da obra (LOBO, 2017, grifo nosso).

Na parceria do Complexo Penal em Minas Gerais (para construção e operação de 5 unidades prisionais para 3000 detentos nos regimes fechado e aberto), assinada em 2009, com valor estimado em $\mathrm{R} \$ 2.111 .476 .080,00$, na área de segurança e modalidade administrativa o que se observa é que o custo do investimento neste tipo de obra acaba sendo bem mais alto para o Estado quando firmado na forma de parceria público-privada:

Nas unidades prisionais privadas (PPPs) são aceitos apenas detentos que não irão apresentar nenhum tipo de problema, recebendo valores muito mais altos que o custo/pessoa em uma prisão pública. Se o Estado tivesse esse tipo de filtro, seria exemplar também (FIDELES, 2017, grifo nosso).

Cada preso tem um custo médio mensal de R\$ 3,5 mil. Metade do valor é o custo real do preso e a outra é referente à construção do complexo. Após quitação da construção o valor integral passa a ser o lucro da concessionária (G1MG, 2017, grifo nosso). 
Nas unidades prisionais públicas, o custo médio mensal é em torno de R \$ 1,3 e 1,7 mil, fora o valor investido na construção de prédios e aquisição de equipamentos (CONSULTOR JURÍDICO, 2016).

Na parceria da Rodovia dos Tamoios (para duplicação e conservação do trecho de serra $(17,08 \mathrm{~km})$ e do trecho de planalto $(3,92 \mathrm{~km})$, assinada em 2014 , com valor estimado em $\mathrm{R} \$$ 3.906.334.654,07, na área de transporte e modalidade patrocinada, observa-se que foi necessário inserir mais recursos para finalizar o projeto e ainda, de acordo com a reportagem, prevalecem os oportunismos eleitoreiros através das inaugurações das obras:

\begin{abstract}
Com um ambicioso calendário de inaugurações para a temporada eleitoral, o governador paulista, Geraldo Alckmin (PSDB), pretende tomar R\$ 2,5 bilhões emprestados para tocar as vitrines de sua gestão. Há uma semana [...] encaminhou, em regime de urgência, projeto de lei à Assembleia que o autoriza a contrair empréstimos para obras do Metrô e da rodovia dos Tamoios. [...] Alckmin pretende aprová-lo ainda neste ano. (FSP, 2017, grifo nosso).
\end{abstract}

Sobre o contrato paulista do Sistema Produtor Alto Tietê (para aumento na capacidade de água tratada na RMSP, 17,7 km de adutoras, 4 reservatórios de $70.000 \mathrm{~m}^{3}$ ), assinado em 2008, com valor estimado em R $\$ 997.377 .948,00$, na área de saneamento e modalidade administrativa, as reportagens tecem uma crítica ao gerencialismo e a lógica do management inserida na Administração Pública, ponderando que esta lógica de mercado faz com que se busque sempre o lucro em detrimento do objetivo maior e final que é prestação do serviço público de qualidade à sociedade. Além disso, nota-se que como "é tudo definido em contrato", a ausência da participação dos diversos interessados, inclusive a participação social, abre espaço para a possibilidade de que os contratos sejam desenhados visando muitas vezes interesses privados e individuais, ferindo o interesse público e dificultando futuros processos de fiscalização e sanção:

Na Sabesp, seu projeto (governador do estado) foi de colocar a maior e mais rentável empresa de saneamento do País sob a lógica do mercado, com ações nas bolsas de valores de São Paulo e Nova York, aprofundando uma visão administrativa, que sempre busca o lucro em detrimento da universalização do saneamento, distribuindo só na última década o montante de mais de R $\$ 5$ bilhões aos acionistas (VICENTE, 2018, grifo nosso).

A ideia é repassar patrimônio ou um serviço rentável para o setor privado, tirando o Estado da atividade-fim nesta área, ficando restrito basicamente ao trabalho de fiscalização e da regulação [...] A estratégia é tornar o setor privado imune a riscos. Isso vem do FMI, do período do governo Fernando Henrique, que estabeleceu que as oportunidades para o setor privado deveriam ser reguladas sem riscos para o mesmo. É tudo definido em contrato. Depois, não tem como o Ministério Público ou o Tribunal de Contas querer auditar (SUL21, 2017, grifo nosso).

\title{
3.2.2 ANÁLISES COMPLEMENTARES
}


A análise documental realizada viabilizou o mapeamento de diversos entraves ou dificuldades que os contratos de PPPs vêm enfrentando na última década no Brasil, especificamente em MG e SP. Notou-se que dentre os principais intervenientes relacionados ao setor de transportes estão: o descumprimento de cláusulas contratuais, irregularidades nas obras e não atendimento aos padrões de qualidade estimados, atrasos na entrega de etapas e da obra como todo, contratos mal elaborados que dão margem para interpretações diversas e inclusive para descumprimentos, inibição do desenvolvimento local por falta de conclusão dos projetos, descontinuidades e rescisões contratuais, fraudes, corrupção, utilização de contratos e inauguração de obras como instrumental para promoção pessoal, eleitoreira e como aporte financeiro para campanhas.

Os estados analisados firmaram contratos em áreas diversificadas sendo elas: esporte, habitação, saneamento, saúde, segurança e transporte. Em São Paulo predominam as parcerias da área de transporte e em Minas Gerais as parcerias referentes à saúde e saneamento. Em São Paulo, 6 contratos dos 11 fechados no período são relacionados a transporte buscando aumentar a infraestrutura da Zona Metropolitana da Capital, além de melhorar a qualidade e sustentabilidade da rede de transporte público. Todo contrato de saneamento, saúde, habitação, segurança e esporte, tanto em MG como em SP são do tipo administrativo, sendo a Administração Pública a usuária direta ou indireta, mesmo que ocorra execução de obra ou fornecimento e instalação de bens. Os contratos de transporte são, com exceção da linha 08 do metrô, do tipo patrocinado, pois nesses casos além da tarifa da passagem que é cobrada dos usuários, há uma complementação de receita feita pela autoridade pública em forma de contraprestação pecuniária para o ente privado. No caso da parceria relacionada à linha do metrô de SP o contrato foi feito por concessão administrativa, pois contempla a prestação de serviços de manutenção preventiva, corretiva, revisão geral e a modernização da frota da Linha 8 da Companhia de Paulista de Trens Metropolitanos.

Em 2012, MG era o estado mais avançado do país em termos de PPPs, tanto pelo número de contratos em execução, quanto pelo montante de recursos públicos destinados às parcerias. Foi reconhecida internacionalmente e eleita pela revista britânica "World Finance" como a melhor unidade de PPP do mundo, por meio da premiação World Finance Awards 2015 (PPP BRASIL, 2015).

A área de saneamento revelou-se uma das modalidades mais usadas em contratos de PPPs do estado de Minas Gerais. As notícias encontradas sobre elas mostram que apesar da 
proposta de trazer soluções de melhoria na área de saneamento para os estados, predomina o atraso nas obras, pela falta de planejamento sobre o impacto ambiental, ou pela fraude em processos de licitação além de outros motivos que envolvem a justiça e agências reguladoras. Conforme artigo publicado pela Sul21(2017) a preocupação do governo é voltada a fornecer garantia para as empresas estatais, que visam sempre o lucro, deixando de se preocupar com a demanda e necessidade da população que sente na pele o impacto destes projetos. $\mathrm{O}$ saneamento é um direito garantido pela constituição, e mesmo como os atrasos e problemas enfrentados pelos contratos a população acaba pagando pelo serviço.

$\mathrm{Na}$ área da saúde em Minas Gerais foram identificados contratos referentes à construção, ampliação e administração das Unidades de Pronto Atendimento (UAIs). Esses contratos buscam a melhoria do atendimento e economia por parte da Administração Pública. Entretanto, o Estado não chegou a divulgar nenhum tipo de dado econômico sobre tal, e reportagens em meios de comunicação públicos são vagas e imprecisas. Em São Paulo a PPP relacionada à saúde é o contrato de construção e manutenção de três hospitais em Sorocaba, São José dos Campos e o Hospital Centro de Referência da Saúde da Mulher - HCRSM. Entregue com três anos de atraso, o hospital de Sorocaba iniciou em abril de 2018 atendimento parcial, assim como o de São José dos Campos, inaugurado em 2014. As obras do HCRSM encontram-se paradas e com atraso de 30 meses devido a impasses relacionados à localização do mesmo.

Na área de Habitação, representada pela PPP do estado de São Paulo, Habitação Moradia de interesse social, foi observado que essa é uma área que segue lentamente na tentativa de resolver a falta de moradia de milhões de brasileiros. O fato é que esta parceria tem sido mostrada como eficiente em discurso político e na prática tem esbarrado com vários problemas, dentre eles problemas sociais, por se tratar de área ocupada por usuários de craque e por excluir determinada classes de pessoas ao destinar as moradias.

$\mathrm{Na}$ área de esporte, a PPP do Mineirão (única no período analisado) se mostra um problema para o Estado. Por se tratar de um contrato de concessão administrativa, prevê que nos meses em que haja prejuízo por parte da empresa o governo aumentará os repasses de verbas, ação essa que é alvo de investigação devido a suspeitas de fraude por parte da administradora. Além da ligação desse tipo de contrato com denúncias ligadas à corrupção política nacional. O que evidencia a dificuldade de fiscalização de forma eficiente do cumprimento do contrato.

No caso das PPPs relacionadas à segurança e complexo penal, observa-se tendência de mercantilização desse tipo de serviço. Como se trata de empresa privada, os custos por detento 
são maiores que os do Estado de Minas Gerais para um serviço prestado de forma seletiva com o objetivo de se obter lucro (FIDELES, 2017).

Todos estes fatores expressam uma necessidade de revisão nos marcos regulatórios e nos mecanismos de fiscalização e controle dos contratos estabelecidos na forma de PPPs. Conforme asseveram Thamer e Lazzarini (2015) os procedimentos precisam ser céleres e mais transparentes de forma a evitar negociações informais que servem apenas para "lubrificar" as engrenagens da burocracia, além disso, os instrumentos de enfrentamento à corrupção atuam como ferramentas importantes para a atração do investimento em infraestrutura ligados a contratos de longa duração. Neste sentido, Lima et al. (2005) também acreditam que dentre os fatores críticos para o sucesso de PPPs estão a existência de legislação adequada, expertise, priorização de projetos e existência de um fluxo regular e previsível de provisão dos serviços e pagamentos, ou seja, ambiente institucional adequado e administração e operacionalização eficiente dos contratos. Adiante, ainda é possível apontar que o incentivo à participação social na gestão deste tipo de contrato, inclusive através dos conselhos gestores, além de fortalecer a democracia, pode atuar como inibidor das "manobras" desenvolvidas pelos agentes envolvidos nos mesmos.

Nesse sentido, dada a gama de problemas e dificuldades enfrentadas pelos contratos analisados, nota-se que de fato há uma necessidade de revisão do arcabouço institucional e legal das PPPs, bem como sobre os aspectos que envolvem a elaboração dos contratos, dos riscos, garantias e mecanismos de fiscalização desse tipo de arranjo, já que suas obras envolvem escopos financeiros expressivos. Assim, esse mecanismo incorporado pela Administração Pública revela-se muitas vezes polêmico uma vez que ao mesmo tempo em que o Estado flexibiliza, delega e divide responsabilidades nesse tipo de contratualização, ele também se torna coautor e pode partilhar de interesses particularistas como decidir quem participará de negociações, quais serão os objetos de ação pública ou mesmo quais atores contemplar, contrariando em muitos casos o princípio da imparcialidade e o caráter técnico-científico das escolhas públicas (CAMPOS, 2009).

Dessa forma, decisões baseadas em acordos entre atores públicos e privados, que possuem interesses diversos e participam de forma desigual da distribuição de poder, arriscamse a consumar-se em um oportunismo para o encontro de interesses pessoais e submissão da autonomia do interesse público a projetos particularistas. Por outro lado, este movimento de descentralização pode ter seus riscos amenizados e garantir a supremacia do interesse público se atuar de forma a permitir maior participação social e fiscalização da ação pública, em um 
contexto onde os marcos regulatórios e a transparência tornam-se elementos fundamentais (CAMPOS, 2009).

\section{CONSIDERAÇÕES FINAIS}

As parcerias público-privadas surgiram no contexto de contratualização das políticas públicas (GAUDIN, 2007) de tendência internacional, seguindo os ideários do New Public Management e do gerencialismo operacionalizado por meio da Reforma do Estado em 1995 no Brasil. O gerencialismo combinou princípios contraditórios de racionalidade e eficiência capitalistas a formas de legitimação política junto à sociedade. Tais características, associadas ao processo de democratização, trouxeram para a gestão, dentre outras, as figuras da accountability, da transparência e da responsabilidade fiscal. A conjuntura para adoção do arranjo das parcerias justificou-se, sobretudo, pelas restrições orçamentárias governamentais, por dificuldades de execução de obras de financiamentos vultosos e de longo prazo, bem como na possibilidade da impressão de maior eficiência por parte do setor privado nestes tipos de contratações.

Entretanto, nota-se que após mais de uma década da promulgação do marco legal deste tipo de parceria no Brasil, prevalece ainda uma gama diversa de problemas e dificuldades a serem enfrentados e solucionados. Do ponto de vista gerencial, nota-se a necessidade de um redesenho mais eficiente dos contratos e de mecanismos de enforcement que possam inibir ou pelo menos amenizar as possibilidades de fraudes, corrupção, desvios, atrasos, prejuízos financeiros e outras improbidades que venham ferir o interesse público, conforme observou-se nos diversos relatos dos contratos em Minas e São Paulo. Algumas experiências internacionais também mostraram como dificuldades, renegociações frequentes e exigências de garantias onerosas.

Sob a ótica da democracia participativa, o que se percebe é que a consulta pública, único instrumento obrigatório, revela-se limitado quanto ao potencial de debate e diversidade do público envolvido, impedindo maior participação da sociedade civil, a quem também interessam as contratações. Ademais, dada a importância das obras executadas e a sua expressão em termos financeiros, mecanismos que assegurem a transparência e accountability precisam ser incorporados a esses tipos de arranjos, fortalecendo o poder de fiscalização sobre estes contratos e o direito de acesso à informação assegurado aos interessados. Sugere-se também a incorporação de membros da sociedade civil, principalmente os afetados pelos acordos, nos 
Conselhos Gestores das PPPs de forma a permitir que as deliberações sejam tomadas de forma democrática e participativa.

O presente trabalho traz como contribuição a análise de Gaudin (2007) que associa a teoria dos contratos à participação para análise das políticas públicas na perspectiva empírica, de modo distinto da bibliografia predominante das PPPs, que as analisam sob a perspectiva da eficiência (THAMER; LAZZARINI, 2015, PECI et al., 2012). A perspectiva que adotamos opera uma abordagem política que as insere no jogo democrático de disputas deliberativas para participação. A conclusão é que instrumentos de participação como os conselhos gestores de parcerias, audiências públicas e consultas públicas são adotados de forma limitante ainda na legislação que dá suporte ao processo. Concluímos que no formato legal, os conselhos gestores preveem a participação exclusiva de representantes políticos do Estado, de agentes técnicos indicados pelo governo e de contratantes da iniciativa privada, sendo facultativa a presença de outros atores. Para sanar a ausência da sociedade civil, as consultas públicas são disponibilizadas à população. Nas consultas não há obrigatoriedade de adoção das medidas propostas, também elimina-se o potencial deliberativo. As audiências públicas, instrumentos importantes de deliberação, devido ao seu formato, são esporadicamente utilizadas.

Salienta-se que o objetivo do artigo não foi realizar um estudo instrumental da eficiência das parcerias, uma vez que as mesmas iniciaram-se recentemente e possuem duração média de 23 anos; assimcomo também não foi estudar o funcionamento dos conselhos gestores sob a perspectiva qualitativa de pesquisa. Acreditamos que o ambiente institucional (econômico, político e social), a existência de um forte marco legal e regulatório e a presença de instrumentos de fiscalização que envolvam o poder público, setor privado e sociedade civil podem atuar mitigando problemas e prevaricações como os revelados, na contratação e operacionalização de obras e serviços públicos.

Como agenda de pesquisa sugere-se estudos comparados entre PPPs europeias e brasileiras segundo as perspectivas reguladoras, da participação popular na modelagem dos contratos, na fiscalização e na avaliação. Sugerimos também a realização de estudos qualitativos sobre a deliberação nas parcerias a partir da forma como ocorrem nos instrumentos de participação: conselhos gestores de parcerias, consultas públicas e audiências públicas.

\section{REFERÊNCIAS}


ALMG. Decreto no 43.702, de 16 de dezembro de 2003. Disponível em: https://www.almg.gov.br/consulte/legislacao/completa/completa.html?tipo=DEC\&num=43 702\&comp $=\& a n o=2003$. Acesso em: 18 ago. 2019.

ALMG. Decreto no 44.565, de 03 de julho de 2007. Disponível em: https://www.legisweb.com.br/legislacao/?id=141494. Acesso em: 18 ago. 2019.

ALMG. Lei no 14.868, de 16 de dezembro de 2003. Disponível em: https://www.almg.gov.br/consulte/legislacao/completa/completa.html?num=14868\&ano=2 003\&tipo=LEI . Acesso em: 18 ago. 2019.

ALMG. Lei Ordinária no 14.869, de 16 de dezembro de 2003. Disponível em: $\mathrm{http} / / /$ leisestaduais.com.br/mg/lei-ordinaria-n-14869-2003-minas-gerais-cria-o-fundo-deparcerias-publico-privadas-do-estado-de-minas-gerais. Acesso em: 18 ago. 2019.

ALMG. Lei Complementar $\mathbf{n}^{\mathbf{0}}$ 91, de 19 de janeiro de 2006. Disponível em: https://www.almg.gov.br/consulte/legislacao/completa/completa.html?tipo=LCP\&num=91 \&ano=2006. Acesso em: 18 ago. 2019.

ALMG. Lei no 18.038, de 12 de janeiro de 2009. Disponível em: https://www.almg.gov.br/consulte/legislacao/completa/completa.html?num=18038\&ano=2 009\&tipo=LEI. Acesso em: 18 ago. 2019.

ALSP. Decreto no 40.000, de 16 de março de 1995. Disponível em: https://www.al.sp.gov.br/norma/11633. Acesso em: 18 ago. 2019.

ALSP. Decreto no 41.150, de 13 de setembro de 1996. Disponível em: https://www.al.sp.gov.br/norma/10075. Acesso em: 18 ago. 2019.

ALSP. Decreto no 48.867, de 10 de agosto de 2004. Disponível em: https://www.al.sp.gov.br/repositorio/legislacao/decreto/2004/decreto-4886710.08.2004.html. Acesso em: 18 ago. 2019.

ALSP. Decreto no 61.371, de 21 de julho de 2015. Disponível em: https://www.al.sp.gov.br/norma/175099. Acesso em: 18 ago. 2019.

ALSP. Lei no 7.835, de 08 de maio de 1992. Disponível em: https://www.al.sp.gov.br/norma/43375. Acesso em: 18 ago. 2019.

ALSP. Lei n 9.361, de 05 de julho de 1996. Disponível em: https://www.al.sp.gov.br/norma/10243. Acesso em: 18 ago. 2019.

ALSP. Lei Complementar n 846, de 04 de junho de 1998. Disponível em: https://www.al.sp.gov.br/norma/6680. Acesso em: 18 ago. 2019.

ALSP. Lei no 11.598, de 15 de dezembro de 2003. Disponível em: https://www.al.sp.gov.br/norma/?id=49123. Acesso em: 18 ago. 2019.

ALSP. Lei no 11.688, de 19 de maio de 2004. Disponível em: https://www.al.sp.gov.br/norma/50875. Acesso em: 18 ago. 2019. 
AVRITZER, L. Teoria Democrática e Deliberação Pública em Habermas e Rawls. In: $25^{\circ}$ Encontro Anual da Anpocs, 2000, Caxambu, Anais... Caxambu: $25^{\circ}$ Encontro Anual da Anpocs, 2000.

BOBBIO, L. Produzione di politiche a mezzo contratti nella pubblica aministrazione italiana. Stato e Mercato, v.58, p. 111-142, 2000.

BRASIL. Decreto n⿳0 8.243, de 23 de maio de 2014. Disponível em: http://www.planalto.gov.br/ccivil_03/_ato2011-2014/2014/decreto/d8243.htm. Acesso em: 18 ago. 2019.

Decreto no 9.759, de 11 de abril de 2019. Disponível em:

http://www.planalto.gov.br/ccivil_03/_ato2019-2022/2019/decreto/D9759.htm. Acesso em: 18 ago. 2019.

BRASIL. Lei no 8.666 de 21 se junho de 1993. Disponível em:

https://www.planalto.gov.br/ccivil_03/Leis/L8666cons.htm. Acesso em: 18 ago. 2019.

Lei no 8.987, de 13 de fevereiro de 1995. Disponível em:

http://www.planalto.gov.br/ccivil_03/leis/L8987cons.htm. Acesso em: 18 ago. 2019.

Lei $\mathbf{n}^{0}$ 9.637, de 15 de maio de 1998. Disponível em:

http://www.planalto.gov.br/ccivil_03/leis/19637.htm. Acesso em: 18 ago. 2019.

Lei $\mathbf{n}^{\mathbf{0}}$ 11.079, de 30 de dezembro de 2004. Disponível em:

http://www.planalto.gov.br/ccivil_03/_ato2004-2006/2004/Lei/L11079.htm. Acesso em: 18 ago. 2019.

Lei no 9.790, de 23 de março de 1999. Disponível em:

http://www.planalto.gov.br/ccivil_03/LEIS/L9790.htm. Acesso em: 18 ago. 2019.

Lei no 13.019, de 31 de julho de 2014. Disponível em:

http://www.planalto.gov.br/ccivil_03/_Ato2011-2014/2014/Lei/L13019.htm. Acesso em: 18 ago. 2019.

BRITO, B. M. B.; SILVEIRA, A. H. P. Parceria público-privada: compreendendo o modelo brasileiro. Revista do Serviço Público, v. 56 n. 1, p 7-21, 2005.

CAMPOS, M. Governar por Contrato. In: I Seminário Nacional de Sociologia Econômica, 2009, Florianópolis, Anais... Florianópolis: I Seminário Nacional de Sociologia Econômica, 2009.

CONSULTOR JURÍDICO. Número de penas de prisão quase dobra em cinco anos e chega a 281 mil em 2015. Consultor Jurídico. [s.i]. 18 out. 2016. Disponível em:

https://www.conjur.com.br/2016-out-18/numero-penas-prisao-dobra-cinco-anos. Acesso em: 18 set. 2019.

COUTINHO, M. Justiça aceita denúncia contra cartel de trens em licitação de $\mathrm{R} \$ 1,8$ bi no governo Serra. Estadão. [s.i]. 26 mar. 2016. Disponível em:

(c) $($ (1) $($ REAd | Porto Alegre - Vol. 26 - N.o 3 - Setembro / Dezembro 2020 - p. 673-708. 
http://politica.estadao.com.br/blogs/fausto-macedo/justica-aceita-denuncia-contra-cartelde-trens-em-licitacao-de-r-18-bi-no-governo-serra. Acesso em: 18 set. 2019.

EXAME. SP inaugura estação da linha Amarela com quatro anos de atraso. Exame. [s.i]. 23 jan. 2018. Disponível em: https://exame.abril.com.br/brasil/sp-inaugura-estacao-da-linhaamarela-com-quatro-anos-de-atraso-2. Acesso em: 18 set. 2019.

FIDELES, N. Superfaturamento e corrupção são as marcas das prisões com gestão privada.

Brasil de Fato. São Paulo. 14 jan. 2017. Disponível em:

https://www.brasildefato.com.br/2017/01/14/superfaturamento-e-corrupcao-sao-as-marcasdas-prisoes-com-gestao-privada. Acesso em: 18 set. 2019.

FREITAS, B.; MELLO, A. Única PPP de estrada em Minas, MG-050 já soma R \$ 58 milhões em multas. Vrum. [s.i]. 10 fev. 2016. Disponível em:

https://estadodeminas.vrum.com.br/app/noticia/noticias/2016/02/10/interna_noticias,51781/un ica-ppp-de-estrada-em-minas-mg-050-ja-soma-r-58-milhoes-em-multas.shtml. Acesso em: 18 set. 2019.

FSP. Alckmin tenta empréstimo bilionário em ano eleitoral. Agora São Paulo. São Paulo. 01 dez. 2017. Disponível em: https://agora.folha.uol.com.br/brasil/2017/12/1939717-alckmintenta-emprestimo-bilionario-em-ano-eleitoral.shtml. Acesso em: 18 set. 2019.

GAUDIN, J.P. Gouverner par Contrat. 2 ed. Paris: Sciences Po Les Presses, 2007.

GAUDIN, J. P.; PEREIRA, M. L. As políticas públicas locais e os processos de "hibridação" no Brasil e na França. In: XXIX Encontro da ANPOCS, 2005, Caxambu, Anais... Caxambu: XXIX Encontro Anual da ANPOCS, 2005. Disponível em:

https://anpocs.com/index.php/papers-29-encontro/gt-25/gt01-17/3630-gaudin-pereira-aspoliticas/file. Acesso em: 10 jul.2019.

GIL, A. C. Métodos e Técnicas de Pesquisa Social. 6. ed. São Paulo: Atlas, 2008.

G1. Justiça aceita denúncia contra cartel em licitação de trens em São Paulo. G1 São

Paulo. [s.i]. 29 mar. 2016. Disponível em: http://g1.globo.com/sao-

paulo/noticia/2016/03/justica-aceita-denuncia-contra-cartel-em-licitacao-de-trens-em-saopaulo.html. Acesso em: 16 ago. 2019.

G1. Delator diz que deu R 6 milhões em caixa 2 para 'Salsicha', tesoureiro da campanha de Alckmin de 2014. G1 São Paulo. São Paulo. 18 abr. 2017b. Disponível em: https://g1.globo.com/sao-paulo/noticia/delator-diz-que-deu-r-6-milhoes-em-caixa-2-parasalsicha-tesoureiro-da-campanha-de-alckmin-de-2014.ghtml. Acesso em: 18 set. 2019.

G1MG. Presídio em regime de PPP em Minas divide opiniões de especialistas. G1. Belo Horizonte.13 jan. 2017. Disponível em: https://g1.globo.com/minas-gerais/noticia/presidioem-regime-de-ppp-em-minas-divide-opinioes-de-especialistas.ghtml

HABERMAS, J. Três modelos normativos de democracia. Lua Nova Revista de Cultura e Política, n. 36, p.39-53, 1995. 
HUNGARO, L. A. As transformações da gestão pública e o governo por contratos: a contratualização das políticas públicas. Revista Digital de Direito Administrativo, v.3. n.2, p.367-383, 2016.

IORY, N. Atraso no metrô de SP pode render lucro para as próprias responsáveis por demora. Último Segundo. [s.i]. 05 dez. 2016. Disponível em:

http://ultimosegundo.ig.com.br/brasil/2016-12-05/linha-4-amarela-metro-sao-pauloviaquatro.html. Acesso em: 18 set. 2019.

KEINERT, T. M. M. Reforma Administrativa nos anos 90: o caso da Prefeitura Municipal de São Paulo. Revista de Administração de Empresas, v.33, n.4, p.66-81, 1993.

LAKATOS, E. M.; MARCONI, M. A. Metodologia do trabalho científico. 4.ed. São Paulo: Atlas, 1992.

LELLES, C. Presidente de associação diz que infraestrutura da MG-050 é um dos entraves para os negócios em Divinópolis. G1 Centro-oeste de Minas. [s.i]. 01 mar. 2018.

Disponível em: https://g1.globo.com/mg/centro-oeste/noticia/presidente-de-associacao-dizque-infraestrutura-da-mg-050-e-um-dos-entraves-para-os-negocios-em-divinopolis.ghtml. Acesso em: 18 set. 2019.

LIMA, J. B. S. et al. Entendendo a parceria público privada no Brasil: uma análise preliminar. Revista do Tribunal de Contas, v. 16, n. 16, p. 103-126, 2005.

LOBO, C. Alckmin prorroga pela quarta vez contrato com concessionária da linha 18. Viatrolebus. [s.i.], p.1-1. 25 mai. 2017. Disponível em:

https://viatrolebus.com.br/2017/05/alckmin-prorroga-pela-quarta-vez-contrato-comconcessionaria-da-linha-18/. Acesso em: 01 jan. 2018.

MELLO, A. Concessionária que explora a MG 050 é alvo de 54 processos. Estado de Minas. [s.i]. 02 mar. 2015. Disponível em:

https://www.em.com.br/app/noticia/politica/2015/03/02/interna_politica,623040/concessao -e-alvo-de-54-processos.shtml. Acesso em: 18 set. 2019.

MGTV. Obras continuam paradas na MG-050, na região de Divinópolis: Segundo Acid, falta de estrutura atrapalha setor empresarial. G1. [s.i]. 24 abr. 2018. Disponível em: https://g1.globo.com/mg/centro-oeste/noticia/obras-continuam-paradas-na-mg-050-naregiao-de-divinopolis.ghtml. Acesso em: 18 set. 2019.

MINAS Gerais recebe novamente prêmio por melhor programa de parcerias público-privadas do mundo. PPP Brasil - O observatório das Parcerias Público-Privadas, 2015. Disponível em: http://www.pppbrasil.com.br/portal/content/minas-gerais-recebenovamente-pr\%C3\%AAmio-por-melhor-programa-de-parcerias-p\%C3\%BAblicoprivadas-do-mu. Acesso em: 18 set. 2019.

MINAS GERAIS. Manual De Operações Do Programa Estadual De Parcerias PúblicoPrivadas De Minas Gerais, 2013. Disponível em: http://www.ppp.mg.gov.br/images/documentos/Consulta/Manual_de_Opera\%C3\%A7\%C3 \%B5es_atual.2013.pdf. Acesso em 18 set. 2019. 
MINAS GERAIS. Estrutura institucional do Governo de Minas Gerais para governança do Programa PPP-MG, 2019. Disponível em: http://www.ppp.mg.gov.br/parceiro/oprograma-ppp/governanca-minas. Acesso em: 18 set. 2019.

MORENO, M. A participação do administrado no processo de elaboração dos contratos de PPP. 2016. 269 f. Dissertação (Mestrado em Direito) - Faculdade de Direito da Universidade de São Paulo, Universidade de São Paulo, São Paulo, 2016.

NOGUEIRA, T. Gestora do Mineirão tem sigilo quebrado: A pedido do MP, Justiça verifica se administradora estaria ocultando possíveis lucros para não repassar valor ao Estado. $\mathbf{O}$ Tempo. [s.i]. 20 out. 2017. Disponível em: https://www.otempo.com.br/superfc/gestorado-mineirão-tem-sigilo-quebrado-1.1533277. Acesso em: 18 set. 2019.

O TEMPO. Fernando Pimentel e Murilo Valadares são condenados por PPP realizada em 2008. O Tempo. [s.i]. 01 maio 2018. Disponível em: https://www.otempo.com.br/capa/política/fernando-pimentel-e-murilo-valadares-sãocondenados-por-ppp-realizada-em-2008-1.1606271. Acesso em: 18 set. 2019.

OLIVEIRA, A. Os atrasos e contradições da Linha 4-Amarela, primeira PPP do metrô. El País. [s.i], p. 1-1. 14 mar. 2017. Disponível em: https://brasil.elpais.com/brasil/2017/01/30/politica/1485802821_227320.html. Acesso em: 18 set. 2019.

PAES DE PAULA, A. Por uma nova gestão pública. São Paulo: Fundação Getúlio Vargas, 2016.

PATEMAN, C. Participação e teoria democrática. Rio de Janeiro: Paz e Terra, 1992.

PECI, A. et al. Parcerias Público-Privadas em Minas Gerais: Racionalidade Técnica versus Política. In: Encontro da EnANPAD, 2010, Rio de Janeiro, Anais... Rio de Janeiro: XXXIV Encontro da Anpad, 2010.

PECI, A. et al. Parcerias Público-Privadas em Minas Gerais: Racionalidade Técnica versus Política. Contabilidade, Gestão e Governança, v.15, n.1, p.80-95, 2012.

PECI, A.; SOBRAL, F. Parcerias Público-Privadas: análise comparativa das experiências britânica e brasileira. Cadernos EBAPE, v. 505, n. 02, p. 1-14, 2007.

PELEGI, A. Operação Lava-Jato trava obras de mobilidade urbana em todo o país. Diário do Transporte. [s.i]. 18 jun. 2017. Disponível em: https://diariodotransporte.com.br/2017/06/18/operacao-lava-jato-trava-obras-demobilidade-urbana-em-todo-o-pais-linha-6-laranja-do-metro-de-sp-e-caso-emblematico/. Acesso em: 18 set. 2019.

PÉRICO, A. E.; REBELATTO, D. A. N. Desafios das parcerias público-privadas (PPPs). Revista Administração Pública, v. 39, n. 5, p. 1031-1052, 2005.

PIRES, B. Da Fonte Nova ao Mineirão, ritmo de investigações de corrupção na Copa destoa. El País. [s.i]. 11 mar. 2018. Disponível em: 
https://brasil.elpais.com/brasil/2018/03/01/deportes/1519862424_958758.html. Acesso em: 18 set. 2019.

CÂMARA, Municipal de Novo Hamburgo. Projeto aprovado amplia participação da sociedade civil em conselho gestor de PPPs. Câmara Municipal de Novo Hamburgo, 2019. Disponível em:

https://portal.camaranh.rs.gov.br/pm3/informacao_e_conhecimento/noticias/projetoaprovado-amplia-participacao-da-sociedade-civil-em-conselho-gestor-de-ppps. Acesso em 18 set. 2019.

QUINTELLA, S. Linha Amarela consolida modelo de estação espalhafatosa na superfície. Veja São Paulo. São Paulo. 06 abr. 2018. Disponível em: https://vejasp.abril.com.br/cidades/metro-sao-paulo-estacoes-arquitetura-criticas/. Acesso em: 18 set. 2019.

REIS, V. Governo de SP inicia processo para encerrar contrato com responsáveis pela Linha 6-Laranja do Metrô. G1 São Paulo. São Paulo. 10 mar. 2018. Disponível em: https://g1.globo.com/sp/sao-paulo/noticia/governo-de-sp-inicia-processo-para-encerrarcontrato-com-responsaveis-pela-linha-6-laranja-do-metro.ghtml. Acesso em: 18 set. 2019.

SÃO PAUlO (Estado). Secretaria de Governo. Programa Estadual de Parcerias PúblicoPrivadas: Projetos contratados. São Paulo, 2015. Disponível em: http://www.parcerias.sp.gov.br/Parcerias/Projetos/Portfolio. Acesso em: 18 set. 2019.

SÃO PAULO. Formação do CGPPP, 2019. Disponível em: http://www.parcerias.sp.gov.br/Parcerias/ConselhoGestor/Estrutura. Acesso em: 18 set. 2019. Acesso em: 18 set. 2019.

SÃO PAULO. Manual de Parcerias do Estado de São Paulo, 2016. Disponível em: http://www.parcerias.sp.gov.br/parcerias/docs/manual_de_parcerias_do_estado_de_sao_pa ulo.pdf. Acesso em: 18 set. 2019.

SEGALLA, V. Esquema no Mineirão desviou R \$ 35 milhões para empreiteiras, aponta MP. UolEsporte. [s.i]. 19 jun. 2016. Disponível em: https://esporte.uol.com.br/futebol/ultimas-noticias/2016/06/19/esquema-desviou-mais-de-r35-mi-para-empreiteiras-do-mineirao-afirma-mp.htm?cmpid=copiaecola. Acesso em: 18 set. 2019.

SILVA, F. C. A. As Parcerias público-privadas no desenvolvimento estatal brasileiro: perspectivas para. Revista Ciências Administrativas, v. 13, n. 2, p. 303-316, 2007.

STOCHERO, T. MP investiga suspeita de fraude na construção da Linha 4-Amarela do Metrô de SP. G1 São Paulo. São Paulo. 10 fev. 2017. Disponível em: https://g1.globo.com/saopaulo/noticia/mp-investiga-suspeita-de-fraude-de-na-construcao-da-linha-4-amarela-dometro-de-sp.ghtml. Acesso em: 18 set. 2019.

SUL21. PPP do saneamento traz enormes riscos para municípios e usuários. Sul21. [s.i]. 06 nov. 2017. Disponível em: https://www.sul21.com.br/entrevistas-2/2017/11/ppp-dosaneamento-traz-enormes-riscos-para-municipios-e-usuarios/. Acesso em: 18 set. 2019. 
THAMER, R.; LAZZARINI, S. G. Projetos de parceria público-privada: fatores que influenciam o avanço dessas iniciativas. Revista de Administração Pública, v. 49, n. 4, p. 819-846, 2015.

VEJA. Camargo Corrêa fecha leniência por cartel em metrô de 7 estados. Veja. [s.i]. 18 dez. 2017. Disponível em: https://veja.abril.com.br/economia/camargo-correa-fecha-lenienciapor-cartel-em-metro-de-7-estados/. Acesso em: 18 set. 2019.

VICENTE, R. A questão ambiental na herança deixada por Alckmin. Portal Vermelho. [s.i]. 26 abr. 2018. Disponível em: http://www.vermelho.org.br/noticia/310310-1. Acesso em: 18 set. 2019. 